European journal of American studies

Special Issue: Race Matters: 1968 as Living History in the Black Freedom Struggle

\title{
Citizens' Councils, Conservatism and White Supremacy in Louisiana, 1964-1972
}

Rebecca Brückmann

\section{CpenEdition}

\section{Journals}

Electronic version

URL: https://journals.openedition.org/ejas/14437

DOI: $10.4000 /$ ejas. 14437

ISSN: 1991-9336

Publisher

European Association for American Studies

Electronic reference

Rebecca Brückmann, "Citizens' Councils, Conservatism and White Supremacy in Louisiana,

1964-1972", European journal of American studies [Online], 14-1 | 2019, Online since 06 July 2019 connection on 08 July 2021. URL: http://journals.openedition.org/ejas/14437 ; DOI: https://doi.org/ 10.4000/ejas. 14437

This text was automatically generated on 8 July 2021.

Creative Commons License 


\title{
Citizens' Councils, Conservatism and White Supremacy in Louisiana, 1964-1972
}

\author{
Rebecca Brückmann
}

1 “Did you ever see anything like it?" asked The Citizen, the Citizens' Councils of America's monthly publication in May 1968. "Within a couple of hours" after Martin Luther King Jr.'s assassination on April 4, 1968, "the nation's Liberal Establishment, official and unofficial," had "donned sackcloth and ashes and plunged into an orgy of publicbreastbeating [sic]," the magazine continued. "Can you imagine any other time in history when a man with the record of MLK could be transformed by the alchemy of propaganda from a real instigator of violence into instant sainthood?" The Citizen opined and concluded that "the wages of integration and 'black power' are violence, anarchy and death." ${ }^{1}$ The conservative Louisiana newspaper The Shreveport Journal, edited by George Shannon, condemned King's "senseless, barbaric" murder pro forma, but noted that "the Rev. Martin Luther King Jr. has become the victim of the passions he excited. His brand of 'non-violence' - provocative and contemptuous of law - begets violence just as violence undisguised does." ${ }^{2}$ In Metairie, a community in the New Orleans Metropolitan Area, the 50-year-old New Orleans native and president of the South Louisiana Citizens' Council (SLCC), Jackson G. Ricau, wrote that to "deplore the assassination is one thing" but denounced the, in his view, "extravagant praise to an imposter who has done more to advance the cause of Communism than perhaps any other person in America." ${ }^{3}$

In what has been termed the "master narrative" of the Civil Rights Movement, the classical phase of civil rights activism started with the Supreme Court's 1954 Brown v. Board of Education verdict, which declared racial segregation in public education as unconstitutional, and culminated in the 1964 Civil Rights Act and 1965 Voting Rights Act that toppled legal segregation and anti-black voting rights restrictions. According to this narrative, by 1966 the movement had begun to unravel; King's assassination during his Memphis campaign in support of the striking sanitation workers marked the 
end of an era. ${ }^{4}$ Confined to the South and centered around the supposedly universally liked Martin Luther King, whom in fact 63 percent of US-Americans disapproved of in a 1966 Gallup poll, this "dominant narrative" framed Black Power activism, the Southern Christian Leadership Conference's post-1965 Poor People's Campaign in pursuit of economic justice, urban riots, and anti-war and social justice activism in the late 1960s and 1970s as detached or substantially different from the earlier, non-violent civil rights struggle. ${ }^{5}$ In her influential 2005 article, the historian Jacquelyn Dowd-Hall criticized this narrative and proposed to re-evaluate a Long Civil Rights Movement that "took root in the liberal and radical milieu of the late 1930s" and transcended a southern sectional experience. ${ }^{6}$ Historiographical critiques have argued that the "long civil rights movement" thesis in turn is too totalizing and glosses over qualitative and quantitative differences in civil rights activism through the decades. ${ }^{7}$

Massive Resistance faces comparable questions. In their comments on King's assassination in 1968 as well as during their Massive Resistance campaign throughout the 1950s and early 1960s, segregationist politicians, grassroots activists, and their media outlets attacked the civil rights movement from a variety of hostile positions, including denouncing civil rights activists as communist agents, condemning what they perceived as a liberal conspiracy against states' rights, and portraying integrationists as outside agitators or lawless rabble rousers. As the historian George Lewis has shown, white supremacist resistance encompassed "a diverse array of ploys and strategies," and political elites as well as grassroots activists shaped Massive Resistance's varied tactics. ${ }^{8}$ Massive Resistance is simultaneously part of a long history of white supremacy and a specific counter-campaign to the Brown decisions in particular and the gains of the civil rights movement in the 1950s and 1960s more broadly. ${ }^{9}$ Similar to the Civil Rights Movement, white supremacist resistance against racial equality did not vanish after the Civil Rights Act of 1964 and Voting Rights Act of 1965. After federal legislation and court decisions dismantled Jim Crow, the grassroots segregationist movement in the South splintered but also formed diverse coalitions. Massive Resistance's grassroots protagonists in Louisiana not only found new homes in the George Wallace presidential campaigns of 1968 and 1972, but exerted discursive influence on broader conservative tropes such as law and order, welfare state reform, and morality. This article examines grassroots segregationist groups in Louisiana between 1964 and 1972, particularly Citizens' Councils, a grassroots movement across the South that originated in Indianola, Mississippi in 1954. Citizens' Councils officially sought to circumvent desegregation in a "respectable," legal manner, but did not shy away from exerting political, social, and economic pressure.

The story of Louisiana's council movement after 1964 is a story of decline, revitalization, coalition building, and diverse survival strategies in a changing social, economic, and political landscape. In the second half of the 1960s, Louisiana's grassroots segregationists were still determined to defend white supremacy and everyday white privileges. They continued tried and tested tactics, including mass mobilization, direct action, and boycotts. In addition, the post-1964 Council movement in Louisiana intensified its white voter mobilization, and put a renewed focus on polarizing, emotional social issues like law and order, welfare, fiscal responsibility, individual morality, and heteropatriarchal discourses on the dangers that desegregation allegedly posed to white women. Segregationist women were vocal 
activists, too, and a number of them played integral roles in keeping the grassroots movement in the public eye.

5 Louisiana's councils sought to re-capture the initiative after 1965. The historian Stephanie Rolph argued that Mississippi's Citizens' Council's "unwavering commitment to white supremacy ensured its continued relevance," and that the Council's "shifting political allegiances [...] ultimately saw success in its convergence" with mainstream conservatism. ${ }^{10}$ Louisiana councils' tactics in the second half of the 1960 s, too, exemplify the fluidity of white supremacy and its compatibility with a range of conservative ideological positions.

Historian Neil McMillen's study on the Citizens' Councils identified two focal points of council activism in Louisiana: the Protestant Northwest and the Catholic Southeast. ${ }^{11}$ In 1955, the first Citizens' Council of Louisiana was founded in Homer, Claiborne Parish, and the parish's stalwart segregationist politician, William M. "Willie" Rainach, became the first president of the state-wide Association of Citizens' Councils a year later. By the Council's first anniversary, twenty-eight of Louisiana's sixty-four parishes had Council chapters, claiming 75,000 to 100,000 members in total. ${ }^{12}$ One of the most influential councils in the state was the Citizens' Council of Greater New Orleans (CCGNO), whose strength McMillen attributed to the "high quality of its leadership," including that of Plaquemines Parish's leader Leander Perez and Dr. Emmett Lee Irwin, the former chief of surgery at Louisiana State University's Medical School and CCGNO president from 1956 until his death in $1965 .{ }^{13}$ Several local councils co-operated in the CCGNO. In the mid-1950s, thousands of people attended the group's rallies, and the CCGNO claimed a membership of up to $50,000 .{ }^{14}$ In 1958, Jackson Ricau, Joseph Viguerie and other CCGNO members withdrew from the council over internal rifts and formed the SLCC which became the second most active group in southern Louisiana. ${ }^{15}$ The SLCC attempted to steer clear of the CCGNO's increasing anti-Semitism, and presented itself as "the more 'respectable' wing" of the local Council movement, counting about 2,000 members in $1960 .^{16}$

7 Already during the 1940s, black activists in Louisiana had intensified their fight for equal access, especially to education. In New Orleans alone, over 50 percent of the city's pupils were black, but their public schools were infamously overcrowded and understaffed, forcing over 10,000 pupils into the platoon system, that is, rotating school hours that allowed the first half of pupils to attend schools in the morning, and the other to then fill their places in the afternoon. ${ }^{17}$ After years of unsuccessful petitions to the Orleans Parish School Board, New Orleans lawyer and civil rights activist Alexander Pierre (A.P.) Tureaud filed suit in 1952 with the support of the National Association for the Advancement of Colored People's Legal Defense and Education Fund. Bush v. Orleans Parish School Board asked for the desegregation of New Orleans' public schools, and thus became a rallying point for the council movement. ${ }^{18}$ When a federal district court ruled that the parish had to proceed with desegregation in 1956, the CCGNO organized mass rallies, supported by numerous state politicians and network ties with other southern states' councils. By 1957, the CCGNO "had more than half" of Louisiana's total council members, McMillen observed. ${ }^{19}$

8 Louisiana never reached the membership numbers of the Council movement's birthplace Mississippi, however. In 1960, only thirty-four out of sixty-four parishes had councils..$^{20}$ Internal strife plagued the movement, and when Louisiana's councils could not prevent the token desegregation of William Frantz and McDonogh No. 19 
Elementary Schools in New Orleans in November 1960, the councils began to collapse. The movement had already shown signs of a downturn by the late 1950s, and when William "Willie" Rainach left the ACCL, the state-wide association whittled into a splinter group. ${ }^{21}$ Both the regional movement and local groups such as the CCGNO faced fewer contributions and less publicity. ${ }^{22}$ By the early 1960s, "the Council movement had disintegrated as a statewide force," concluded the historian Adam Fairclough. ${ }^{23}$ The remaining council movement in the 1960s was characterized by a struggle against its influence's erosion and constant infighting. In February 1962, the Shreveport attorney and ACCL president Charles L. Barnett sent a letter to Willie Rainach to initiate a meeting at Alexandria, writing that "[r] igor mortis has about set in on the Council. Maybe we ought to at least have a meeting and say a few final words." Months later, Rainach proposed to re-organize the state's council movement by following the organizational models of labor unions. The new statewide organization 'Citizens' Councils of Louisiana, Inc." resulted from this effort. ${ }^{24}$

In the meantime, Louisiana's council movement experienced a short second spring with its nationally publicized "Freedom Rides North" campaign. Initiated by CCGNO executive and Perez aid George Singelmann, these "reverse" Freedom Rides solicited black families from the South for one-way bus and train tickets to Northern destinations, including Chicago, New York, and Hyannis, Massachusetts, near the Kennedy's residence. Although condemned even by local media who called the CCGNO's publicity stunt "sick sensationalism, bordering on the moronic," the council was successful in evoking nationwide publicity and reinvigorating its organization. The Citizens' Council of Louisiana successfully solicited funds from its members to permanently establish its biweekly newspaper The Councilor, and the group's finance committee chairman Rainach, secretary-treasurer Touchstone, and president Barnett cited the Freedom Rides North as the "first prong" of their renewed "offensive." 25

By 1964, however, the state organization was again preoccupied with internal rifts. Charles Barnett and Willie Rainach accused Ned Touchstone and the Shreveport council official Courtney Smith of grandstanding. Touchstone met the reproach by accusing Rainach and Barnett of inaction. Additionally, the council fought over Rainach's support for the Republican candidate Charlton Lyons over Democrat John J. McKeithen in Louisiana's 1964 gubernatorial election as well as The Councilor's topical direction. This spat led to the expulsion of Touchstone and Smith from the Citizens' Council of Louisiana's board of directors and marked "an official break" in the organization during the year of the passage of the Civil Rights Act, Rainach later recalled. Touchstone and Smith, however, stood their ground in Shreveport and continued the newspaper's publication, which became increasingly conspiratorial and rabidly racist and anti-Semitic in the late 1960s and early 1970s. In 1972, Ned Touchstone was accused of embezzling. ${ }^{26}$

11 The SLCC under Jackson Ricau, meanwhile, continued its steady stream of propaganda throughout the mid-1960s but had little pull in terms of public mobilization. In 1964, the SLCC supported Barry Goldwater's presidential bid and, like Rainach, Lyons for governor. The SLCC urged the repeal of the Civil Rights Act which the Council deemed a violation of the Thirteenth Amendment's anti-slavery provisions, because, in their view, "[f]orcing anyone to serve another against his wishes is [...] 'involuntary servitude,' and therefore in plain violation of the Constitution." ${ }^{27}$ In 1965, the SLCC campaigned against the appointment of the Archdiocese of New Orleans's first black 
auxiliary bishop Harold R. Perry. The SLCC, personified through Ricau, entangled its white supremacy with conservative tropes of individualism and freedom of choice, but continuously failed to steer clear of race baiting. Ricau, for example, stressed to fellow council members in 1965 that, in his view, conservatives were "by far the most powerful pressure group in America," and stated that "the emotional appeal inherent in the racial issue" would promise success if "the Nordic people" stood up "before the last remaining pure whites wind up with their backs against the Rio Grande." 28

Despite the SLCC's grandstanding rhetoric and the ACCL's repeated attempts at reorganization, by the time the Civil Rights Act passed in 1964, the regional council movement's influence on Louisiana politics had waned. There were, however, enclaves of continuous activism and successful solicitation of publicity for council policies, centered in New Orleans and the surrounding parishes as well as in Shreveport. These councils' actions continued well into the 1970s. Keenly aware of their deteriorating strength, these Louisiana grassroots segregationists sought alliances with other white supremacist (splinter) groups, including the Ku Klux Klan (KKK), and were still able to mobilize thousands of supporters. Council officials in Louisiana diversified their activism and talking points, moreover, to incorporate conservative themes, which enabled them to transcend the narrow scope of anti-desegregation activism and find a footing among broader conservative conversations. ${ }^{29}$

Despite council members' attempts to cloak their white supremacists interests in the colorblind rhetoric of "law and order" or "freedom of choice" conservatism, this language was never more than a thin veneer for their underlying racism. Nonetheless, grassroots segregationists' actions were able to infuse white supremacy into mainstream conversations, and the segregationist counter-movement's protagonists continued to exert influence on public discourses even after their membership numbers dwindled and their funds thus dried up.

14 In 1965, the CCGNO and the SLCC kicked back into gear at Bogalusa, Washington Parish. The historian Adam Fairclough has termed the crisis of Bogalusa "a landmark, a turning point" in Louisiana's civil rights movement. Racial tensions erupted in this rural town between 1964 and 1966 and again in 1967 when the local high school desegregated. Local black community leaders and Congress of Racial Equality (CORE) activists challenged the continued segregation of public facilities in this town dominated by the Crown-Zellerbach sawmill. Civil rights activists pressed for the desegregation of all public facilities, and they urged improvements to black neighborhoods and the employment of black police officers and black civil servants. When Bogalusa mayor Jesse Cutrer's assurances yielded few results, black activists picketed downtown stores and entered establishments in order to "test" the town's Civil Rights Act compliance. ${ }^{30}$

15 Segregationists' reactions were swift. The local Original Knights of the Ku Klux Klan (OKKK) blossomed and included local civil and business leaders. The Klan was a force to be reckoned with in Louisiana in the mid-1960s. The Anti-Defamation League estimated that by 1965 , seventeen klaverns with about 1,000 members had been established. The League deemed several of them "extremely militant and violent." ${ }^{11}$ The Southern Conference Education Fund reported that in 1965, about eight hundred KKK members lived in Bogalusa and many more in the surrounding areas, "the largest per capita concentration of Klansmen in the nation." ${ }^{32}$ 

on black children. Bogalusa's local police force was at least sympathetic to the white supremacist cause, and law enforcement ceased until the Justice Department filed contempt charges and federal courts issued injunctions against the KKK's interference and the police's negligence. ${ }^{33}$ White supremacists' violence and the police's refusal to protect black civil rights workers put the national spotlight on the Deacons for Defense and Justice between 1965 and 1966, black activists who protected demonstrations and served as armed security detail for black rights campaigners. ${ }^{34}$

Black Louisianans could not count on the state's political officials, either. Both Governor McKeithen and Bogalusa mayor Cutrer equated civil rights and white supremacist activism. Cutrer, for example, praised a segregationist parade and rally as "very orderly and well conducted" and "carried out in such a manner as to reflect credit on the local citizens who organized it," thereby taking a swipe at CORE officials like James Farmer whom he deemed an outsider. Cutrer also complained that the civil rights movement had "cost the city $\$ 96,000$ " during the first half of 1965 for increased police presence and related expenses. McKeithen stated that Louisiana had no need for the KKK, but he also called Farmer "trash." The governor thus echoed the SLCC, who had warned him in an open letter that Farmer was a "known trouble-maker" and an "outside agitator" who should be kept out of Louisiana..$^{35}$ The mounting confrontations between white supremacists and black activists in Bogalusa eventually forced the state's and federal government's hand, however. McKeithen dispatched a three-men committee, comprised of state senator Michael O'Keeffe, Alexandria lawyer Camille Gravel, and state AFL-CIO leader Victor Bussie, to mediate. ${ }^{36}$

the CCGNO learned of the governor's mediating committee in April 1965, it asked to be included in the "negotiations and mediation." Bussie rebuffed the council's demand by stating that the committee "was concerned with Bogalusa, not New Orleans." ${ }^{37}$ The CCGNO had sensed an opportunity to reinvigorate its group, however. Four days after the CCGNO unsuccessfully asked to be included in the mediation attempt, it made its true intentions clear when it announced a segregationist rally in cooperation with the United Conservatives of Louisiana (UCL) at a press conference. Denouncing the Bogalusa mediation committee, CCGNO executive secretary George L. Singelmann proclaimed that Alabama Sheriff James Clarke, district judge John Rarick, and Leander Perez would speak at the rally (albeit the latter's speech was thwarted by McKeithen's intervention, a fact the CCGNO bitterly decried at their rally). Singelmann also hinted that the council would charter busses to bring people from New Orleans to Bogalusa. The UCL's and CCGNO's press conference's moderator, James M. Ellis, stressed that their protest rally was "not of a racial nature" but "a conservative movement." 38 Six months later, James M. Ellis, an auto repairman, would be revealed as a KKK member by Georgia Representative Charles L. Weltner, who, in order to expose the Klan's influence in Bogalusa, placed Ellis's and other members' names in the Congressional Record. ${ }^{39}$

The CCGNO was in the midst of the Bogalusa commotion. Their actions illustrate that the group had no qualms to align itself with the most extreme Ku Klux Klan forces in order to defend white supremacy and to stay relevant. Their campaign also shows that Bogalusa was the last hurrah of ordinary CCGNO mobilization tactics, that is, activating the white community for large rallies and drumming up publicity. During the spring 
and summer of 1965, the CCGNO piggy-backed on the KKK, and the CCGNO's most active official in Bogalusa, Jack Helm, was also a KKK member. ${ }^{40}$

Although - or because - the CCGNO's actions in Bogalusa were entangled with the Klan from the start, cloaking their white supremacist activism in the colorblind rhetoric of conservatism became one of the CCGNO's main strategies. At the May 7, 1965 rally, which the Times Picayune reported as a cry for the "return of conservatism," district judge and future Congressman John Rarick was the main speaker. Rarick lamented the lack of official support for the rally. He alluded to conspiracy theories about paid protesters in the Civil Rights Movement when he stated that "[n]o one has paid you $\$ 10$ for marching." Rarick proclaimed that the segregationist protesters were "telling the world this is our country. We want our country back." Rarick denounced that Voting Rights Act, and he declared that he favored "segregation not because of hate or fear" but because he was "a free man." If Martin Luther King were successful, Rarick continued, "there will be no such thing as freedom." He urged the crowd to "stand up for America and for individual freedom," which allowed them to "discriminate against anyone we may choose [...]." ${ }^{\prime 11} \mathrm{~A}$ who-is-who of Louisiana's council movement took to the podium, including Singelmann, Courtney Smith, Ned Touchstone, and William Simmons, executive director of the Citizens' Councils of America, who urged the crowd to support George Wallace. The turnout was solid: the police estimated that 2,000 people had attended a prior protest march, waving small confederate flags. Around 3,000 assembled for the subsequent rally at Goodyear Park. ${ }^{42}$

21 For the CCGNO, the Bogalusa mobilization was a prime possibility to revitalize its influence. The group's Bogalusa campaign sought to mobilize local and regional, direct action resistance against desegregation that had slowed down since the early 1960s, but the group simultaneously attempted to transcend a southern sectional battle by appealing to supposedly trans-regional, conservative policies and strategies to circumvent racial equality.

Notoriously hard to pin down, conservatism after the Second World War has been described "as a social and political movement" of intellectuals and grassroots activists who eventually established "a mass following" and substantial "influence over the Republican party," according to the historian Kim Philipps-Fein. ${ }^{43}$ The tenets and ideological roots of this new wave of conservatism are varied, but they include traditionalism, anti-communism, backlash to racial equality and liberal social movements, laissez-faire capitalism, opposition to governmental interventions (including the New Deal and Johnson's Great Society), and freedom of choice, often emanating from suburbia. ${ }^{44}$ Understood as less of a fixed category and more of "a collective identity that evolves in the course of struggles and collaborations over meaning," as the sociologists Neil Gross, Thomas Medvetz, and Rupert Russell argued, Louisiana's councils found compatibilities with conservative ideology in their quest for continued white supremacy. In Bogalusa, the CCGNO tested the water. ${ }^{45}$

Shortly after the passage of the Voting Rights Act and while the white supremacist mobilization in Bogalusa crested in the summer of 1965, the CCGNO had a kick-off rally for several voter registration events in an attempt to register as many white people as possible. The CCGNO's acting chairman C.E. Vetter organized small neighborhood rallies, and Jack Helm, a member of the group's board of directors, was slated as a speaker to "prove to the crowd that the [...] Voting Rights Act was written by the Communist Party of the United States." The CCGNO proclaimed the (hopelessly 
unrealistic) goal of registering 60,000 white voters in New Orleans between August and October $1965 .{ }^{46}$ With the electoral flank covered, the CCGNO also put forth a legal strategy to defend white supremacy in Bogalusa. Singelmann announced "new legal approaches to the racial situation" in July 1965. In cooperation with the National States' Rights Party, the CCGNO filed affidavits against black civil rights leaders, which charged that they had violated Louisiana law that forbade common-law marriages. ${ }^{47} \mathrm{Hitting}$ civil rights activists with charges of immorality would soon become one of the CCGNO's preferred strategies.

Before the Bogalusa segregation rally at Goodyear Park on May 7, 1965 came to a close with a "Dixie" sing-along and a benediction, the CCGNO's official Jack Helm gave a final address. Helm had stepped onto the public scene in 1963 as president of Parents and Friends of Catholic Children, Inc., a segregationist New Orleans organization which opposed the desegregation of parochial schools. In Bogalusa, Helm told the crowd that he was "glad to be here with you white, God-fearing citizens; and God is with us." His direct invocation of whiteness was no coincidence: Helm was Louisiana's grand dragon of the United Klans of America (UKA), and he served as a linchpin between the council movement and Louisiana's Klans in the early to mid-1960s. ${ }^{48}$

Helm's Klan affiliation was not a secret. Only three weeks later, he was announced as a "leader of the Citizens Council of Greater New Orleans and principal speaker" at a Bogalusa Klan rally. ${ }^{49}$ Again in mid-July 1965, Jack Helm was introduced in his official capacity as a CCGNO official and spoke at a well-attended Klan rally on a farm in nearby Crossroads, Mississippi..$^{50}$ The collaboration between klaverns and other white supremacist grassroots groups in Washington Parish and the neighboring Mississippi delta resulted in several big rallies during the summer of 1965 , in which council and Klan members alike denounced civil rights activists and federal officials, whom UKA's Imperial Wizard Robert Shelton called "tennis-shoe wearing [...] sex perverts." ${ }^{51}$

The Klan's reascent in Louisiana did not go unchallenged. In the autumn and winter of 1965 and 1966, the House Un-American Activities Committee began to investigate the Klan's actions in Louisiana. In October 1965, Helm spoke at a UKA rally in Philadelphia, Mississippi, which was also attended by several people under indictment for the Mississippi Freedom Summer murders of Michael Schwerner, James Chaney, and Andrew Goodman. Helm introduced himself as a representative of the "Louisiana Citizens Council" and told the crowd that the congressional investigation into the KKK would not harm the Klan. Helm assured his audience that the group would still be here when the Congressmen "are dead and buried and I hope it will be soon." ${ }^{52}$ In January 1966, Helm became one of the six Louisiana men whom the House committee questioned in D.C. The fifty-five-year-old declined to answer but wore a "large confederate flag emblem on his lapel." ${ }^{3}$

A month later, Helm appeared at a meeting of the Citizens' Councils of Louisiana's board of directors with the support of Ned Touchstone. Helm's public association with the Klan made him a liability to the CCGNO. Whereas prior to the congressional hearing, Helm, also in his capacity as president of Parents and Friends of Catholic Children, Inc., was still on the roster of speakers at CCGNO events, the UKA official lost his standing with the majority of the Council. His affiliations with a racist terror organization could no longer be ignored or obfuscated. Helm was fired from his job at L.P. Smith \& Company in New Orleans, for which he had worked for twenty years, and suspended as local draft board chairman of the Selective Service. ${ }^{54}$ Out in the open as 
Louisiana UKA's grand dragon in 1966, Helm received a triumphant return to the Klan after his testimony in D.C., however, when seventeen klaverns rallied in New Orleans, dedicating their meeting to the theme "Jack M. Helm Is Coming Home." Helm then became the Imperial Dragon of the Universal Klans of America, a group of South Louisiana Klan members who split from the UKA in 1967. When Victor Bussie's home was bombed in Baton Rouge the same year, Helm was at the center of police investigations. He denied any involvement. ${ }^{55}$

Despite the CCGNO's silence on their member Jack Helm's actions, the KKK official was not the only white supremacist extremist linked to the group in the mid-1960s. On May 30, 1965, the black Washington Parish sheriff's deputy O'Neal Moore and his partner Creed Rogers drove their patrol car near Bogalusa, when a man in a passing pickup truck shot at them. Moore, a father of four daughters, was killed. The police arrested the 41-year-old former Marine Ernest McElveen who worked at the Bogalusa's papermill. McElveen, who was charged with murder, was a CCGNO member, a member of the National States' Rights Party, and a member of the National Rifle Association. Neither McElveen nor the men whom the police thought to be co-conspirators were convicted due to a lack of evidence..$^{56}$

In Bogalusa, the CCGNO walked the line between its customary white supremacist agitation and an outright alignment with the KKK. After Jack Helm's public exposure, he ceased to be a public official for the group, who seems to have feared (further) bad press. While the CCGNO's interventions in Bogalusa on the one hand showed that the group could rally substantial grassroots support for white supremacy and was not anathema to cooperating with the KKK, on the other hand the crisis masked the fact that Bogalusa was one of the few instances in which regional cooperation between segregationist grassroots groups to defend white supremacy were successful. Finding and creating opportunities to unify the fractured council movement in Louisiana was crucial to its continuance, however. Bogalusa proved valuable here, as did state and national electoral politics.

The passage of the Voting Rights Act in 1965 put the council movement across the South on the defensive. Willie Rainach readily admitted in 1977 that prior to the Act, the Louisiana Joint Legislative Committee on Segregation, in tandem with the state's councils, had harassed voter registrars and purged voting rolls of supposedly "unqualified" or "improperly registered" voters. ${ }^{57}$ After the passage of federal civil rights and voting rights legislation, Louisiana councils not only called upon Governor McKeithen to reject federal aid funds rather than to integrate the state's public schools, they initiated white voter registration drives to counter black voter registrations..$^{58} \mathrm{In}$ 1965, Leander Perez warned that the CCGNO had to "get organized, get registered and vote," because unless white people casted a bloc vote, the country's future would not be "a pleasant picture." Perez asked for 122,000 additional white voters to fight "the curse of the Second Reconstruction period for the South." The CCGNO's acting chairman, C.E. Vetter announced plans for neighborhood voter registration meetings. Vetter remarked that this action marked "a new policy" for the Council, which was now actively seeking out supporters instead of asking people to come to them. The CCGNO even offered car rides to voter registrar's offices - an illustration of the organization's waning mobilization strength. Indeed, the CCGNO's finances were just as dire: in June 1965 , Vetter admitted that only half of the council members had paid their annual dues since the beginning of the year..$^{59}$ 
31 Electoral politics, nonetheless, proved another rallying point for the struggling councils. In March 1965, 300 delegates of the Citizens' Council of Louisiana attended a strategy meeting in Baton Rouge when they heard about a possible Voting Rights Bill. Half the group marched over to the governor's mansion, where they confronted McKeithen in his morning clothes and in search of a cup of coffee. McKeithen assured the agitated councilmen, including Shreveport's Courtney Smith, that he had no intention of supporting the legislation. ${ }^{60}$ When the Voting Rights Act passed a few months later, the councils in North and South Louisiana alike found themselves on the backfoot. They, too, started white voter drivers and rallied white communities against black candidates. "Do you want Negro's [sic] elected to office in Shreveport?" the Shreveport Citizens' Council asked its members, urging them to double their efforts. ${ }^{61}$ In New Orleans's Ninth Ward, the site of the city's first public school desegregations in 1960, the CCGNO campaigned furiously against Nils Douglas, a black civil rights attorney who ran for the state legislature. "The white voters of the $9^{\text {th }}$ Ward are faced with the most serious challenge since Reconstruction time," the council wrote, and urged its alleged "10,000 present and former members" in the area to cast their ballot for Ernest J. Hessler, Jr. ${ }^{62}$ Douglas lost to the segregationist Hessler, but he organized the Southern Organization for Unified Leadership (SOUL) to mobilize black voters. In 1973, Douglas was appointed as Orleans Parish Criminal District Court Commissioner. Ernest "Dutch" Morial became the first black state Representative since Reconstruction in $1966 .^{63}$

In contrast, John R. Rarick, judge of the $20^{\text {th }}$ judicial district court at St. Francisville, became the great white hope for the councils. Rarick, who had made a name for himself by issuing a restraining order against picketing CORE members in East Feliciana Parish, ousted 24-year veteran U.S. Representative James H. Morrison in the $6^{\text {th }}$ district Democratic primary runoff in September $1966 .{ }^{64}$ Rarick, whom historian Fairclough deemed "one of the most extreme and politically ambiguous segregationists in the state," was a native of Goshen, Indiana, and had come to Louisiana as an army trainee during the Second World War. He had not only been a frequent speaker at CCGNO events but also "cultivated" the support of the KKK. ${ }^{65}$ Rarick, nonetheless, threatened to sue his opponent Morrison for libel when the latter distributed campaign cards that showed Rarick's name with a picture of a robed Klansman. The CCGNO campaigned vigorously for Rarick, and he beat out Morrison by 5,000 votes. When Rarick challenged McKeithen for the governorship in 1967, however, he was soundly defeated. ${ }^{66}$

Rarick, who in a speech to the $77^{\text {th }}$ continental Congress of the Daughters of the American Revolution (DAR), two weeks after King's assassination, said that King had "showed more disrespect for the law and did more to aid and abet communist causes than all peace-marchers in the land" to repeated applause, also pledged his support to George Wallace's presidential campaign. House Democrats subsequently stripped Rarick of his seniority, and he lost the race for assistant Democratic Senate leader to Edward M. Kennedy. ${ }^{67}$

Seeing themselves as outcasts from the Democratic Party, Louisiana segregationists joined Wallace's 1968 presidential bid in droves, a campaign that helped "unify some of the key players" of southern Massive Resistance and national groups of the grassroots right. ${ }^{68}$ During his Democratic presidential campaign in 1964, Wallace had already wooed Louisiana's council movement. ${ }^{69}$ In 1967, Wallace was the principal speaker at the Citizens' Councils of America's annual leadership in New Orleans. He shared a 
podium with Louisiana's right-wing political elite, including Leander Perez and Lieutenant Governor Aycock. In his address "Stand Up For America," Wallace insinuated that neither party could stop his candidacy or his "mass movement." In April 1967, 2,000 people assembled at a \$25-a-plate dinner in Baton Rouge honoring him and Lurleen Wallace, the Governor of Alabama and George's wife who had vowed to defy the federal court order of Lee v. Macon County Board of Education to desegregate Alabama's schools, the SLCC reported enthusiastically. ${ }^{70}$ Wallace's presidential ambitions invigorated the council movement in Louisiana across internal fractions.

Louisiana's councils took the plunge into fulltime support for Wallace's American Independent Party in 1968. "Everyone's tied up in this thing," commented Singelmann, executive director of the CCGNO in October 1968, who ran the downtown section of four headquarters in New Orleans's metropolitan area. Citizens' Councils successfully drove petitions in their "Operation Dixie" to place Wallace on the Louisiana ballot. Leander Perez served as the state chairman of the Louisiana Wallace Campaign Fund. Singelmann stated that the Wallace campaign schedule left him with no time for his usual CCGNO duties, but fervently praised the campaign efforts as "amazing, just fantastic," and a mobilizing tool for many young people. The councils were not only fighting to survive, they wanted to cultivate a continuous force for white supremacy by recruiting young whites. Wallace easily carried Louisiana in November $1968 .{ }^{71}$

Louisiana's grassroots coalition for George Wallace unraveled after the presidential election, however. Two camps, one surrounding Wallace presidential elector Dr. S.R. Abramson, and one George Singelmann, argued over who was the legitimate American Party of Louisiana heir. The segregationists eventually settled the dispute, and both Singelmann and Abramson represented their respective districts at the party convention in Baton Rouge in January 1969.72 The American Party of Louisiana ran newspaper advertisements which asked members of the two parties to change their affiliation from "the Hubert H. Humphrey party, the Rockefeller party, the Nixon party, to the real alternative, the American Party," an undertaking that the Alexandria Daily Town Talk called "ineffectual." Although the American Party of Louisiana organized several groups under the title of "Association of Wallace Voters" in the spring of 1969 in order to siphon off voters from the major parties, Democratic candidates throughout the next years easily won their campaigns against Republican or American Party candidates. By 1968, the state's black voter numbers had nearly doubled since 1964. In 1969, C.E. Vetter wrote to Ned Touchstone that the Citizens' Council of Louisiana "is non existent [sic] at this time and we will find ourselves in deep water if we don't look out." ${ }^{73}$ The revitalization of the state organization did not come about. In 1972, Roy M. Harris, president of the Citizens' Council of America, predicted that if Wallace did not receive the Democratic presidential nomination, "the entire South" would go for Richard Nixon. After Wallace bowed out after surviving an assassination attempt, Nixon proved the effectiveness of the Southern Strategy and carried Louisiana. ${ }^{74}$

Southern resistance to school desegregation was ongoing after the Civil Rights Act, and white flight came into full effect. In Louisiana in 1966, sixty-five segregated private schools enrolled approximately 16,500 students. Even in cosmopolitan New Orleans, almost no residential integration had occurred for the past nineteen years, a city report noted in 1969, and black residents were "concentrated in public housing projects." Louisiana's council movement fought hard to preserve this status quo in the second half of the 1960s. By 1966, only fourteen parishes had remaining active councils, 
however, which collected annual membership dues of $\$ 3.00 .{ }^{76}$ Courtney Smith urged fellow council members to not give up and encouraged them to get creative in order to refill their ranks: "Do whatever is necessary to draw a crowd. Hire a band - have a local talent contest - bring a speaker that will draw - hold a cake auction - arrange a debate [...]. THINK!"77

In addition to councils' attempts to mobilize white supremacists with direct action and white voter drives, grassroots segregationists, in cooperation with political officials, patrolled the boundaries of white supremacy through social issues. In 1964 and 1965, the CCGNO called for a boycott against car manufacturer Ford and other companies they deemed integrationist, and it urged white people to stop buying music records by black artists. That same year, the group organized a New Orleans rally in May to condemn the $10^{\text {th }}$ anniversary of Brown v. Board of Education, at which George Singelmann declared that if school desegregation proceeded at the same pace as it had in the past decade, it would take another "870 years to finish the job."

Notwithstanding Singelmann's frequent racist outbursts, in the mid- to late 1960s, the councils again sought to activate "ordinary" white citizens against racial equalization, and they utilized a broader, conservative, and supposedly colorblind jargon on freedom of (school) choice and individual liberties, welfare and fiscal responsibility, law and order, and morality. ${ }^{79}$ The timing was right. Between 1968 and 1969, Louisiana's council movement tapped into public moral panics about (the intersections) of civil rights and anti-war protests, the women's liberation movement and changing sexual mores (including the Supreme Court verdict in Loving v. Virginia in 1967, which rendered Louisiana's racial "intermarriage" laws unconstitutional), the welfare (state) expansion of Johnson's Great Society, and fears of riots, increasing crime rates, and a supposedly impending "race war" run by Black Power advocates..$^{80}$ The Shreveport Journal and the Shreveport Times regularly published pieces that accused Martin Luther King and other civil rights and student protestors of associating with "militants" and stressed their responsibility for the possible "touch off" of a "guerilla warfare summer." The CCGNO and the SLCC seized on this sensationalist climate and refuted the "myth of inevitability" they said falsely surrounded desegregation. ${ }^{81}$

The CCGNO embarked on a "crusade to save our children" in May 1967, a series of meetings that urged resistance to federal guidelines on school desegregation, and pleaded with Louisiana's officials to reject federal funds rather than to desegregate. ${ }^{82}$ The CCGNO and SLCC continued their defamation campaigns against prominent civil rights activists, including Martin Luther King, James Farmer, and Urban League director Whitney M. Young, Jr..$^{83}$ In 1969, the CCGNO appropriated civil rights rhetoric when Singelmann and several men and women staged a "peaceful sit-in," as he called the group's actions, at the New Orleans city council to protest the removal of the Confederate flag at city hall. ${ }^{84}$

41 The CCGNO's and SLCC's most tenacious strategy to reach mainstream audiences was interweaving racial allusions and gendered fears with the rhetoric of law and order, morality, and individual responsibility. Rehashing a white supremacist favorite, both groups warned of the dangers that desegregation allegedly posed to white girls and women. The SLCC made good on its promise to win over conservative voters by appealing to the emotional aspect of racial equality and published sensationalist allegations of arranged transportation for white Catholic school girls to the homes of black boys for "social visits." This white supremacist, heteropatriarchal outlook on 
white women was echoed by a CCGNO's meeting that provided "self-defense instruction for women." Advertisements in southern council publications for a pepper "selfdefense spray" for women made racialized allusions to having been tested on the mean streets of Chicago. ${ }^{85}$ In connection, Louisiana's councils reverted to a masculinist discourse on law and order, particularly in connection to crimes against white women. In January 1968, the CCGNO urged Governor McKeithen "to sign the death warrants for all convicted rapists now confined to death row at Angola." Council chairman Vetter elaborated that his was the "only hope we have of being able to walk the streets again without fear of bodily harm." ${ }^{\circ 6}$

Despite this stylization of white female victimhood, white women were also vocal segregationists in Louisiana. Several officials of the Shreveport Citizens' Council, founded in 1963, were women. ${ }^{87}$ The most infamous women's group were the so-called Cheerleaders, a gathering of neighborhood women and female council members who protested the desegregation of William Frantz and McDonogh No. in 1960 and $1961 .{ }^{88} \mathrm{~A}$ prominent member of the core group of Cheerleaders who assembled everyday was Una Gaillot, who had also founded her own organization, "Save Our Nation, Inc." (a play on the integration supporting, liberal group "Save Our Schools"). Born in 1920, Gaillot was a religious fanatic and segregationist militant to whom desegregation was a religious principle, on which she published a number of pamphlets. The mother of three was excommunicated from the Catholic Church alongside Jackson Ricau and Leander Perez in 1962 for her segregationist agitation. ${ }^{89}$ Whereas Perez was supposedly repentant and thus quietly re-admitted to the church before his death, Una Gaillot officially "renounced" the church in 1969 and confirmed her white supremacist views. ${ }^{90}$ In the mid- to late 1960s and early 1970s, Gaillot was still a segregationist activst. She protested her son Kenneth's integrated army unit, the hiring of black priests, and unsuccessfully took to court to enforce the racial labeling of banked blood in state hospitals. ${ }^{91}$ Louisiana's council movement, alike to right-wing movements across the nation, was male-dominated in rhetoric and official personnel; however, women were far from being mere pawns.

In the mid-1960s, the councils also dismissed or ridiculed black civil rights activists' experiences with violence and police brutality. In May 1966, the SLCC pushed backed against civil rights activists' demands for a civilian police review board in New Orleans. "What with Watts still fresh in our minds," the SLCC wrote, "the spurious allegations" of police violence were particularly non-credible. Instead of backing a review board, people should "strengthen" the police department "in case of attack this summer by Negro revolutionaries." ${ }^{92}$ A few months later, the SLCC again asked for more support for the police, charging that the Civil Rights Act had exacerbated crime rates. If the federal civil rights and voting rights legislation were repealed, the SLCC continued, the country could return to "constitutional government and reduce crime [...]." ${ }^{93}$ The SLCC also stoked panic of Black Power, calling it the "domination over the Whites in every field of endeavor [...]." ${ }^{94}$

44 The council movement's other social focus was state and federal spending. When calling upon the governor to reject federal aid to education rather than to integrate the state's public facilities in February 1965, the Citizens' Councils of Louisiana simultaneously presented a resolution that asked McKeithen to initiate "a statewide voluntary birth-control program in all state health facilities" as a means of saving money and replacing lost federal funds. ${ }^{95}$ The state organization's representatives and 
McKeithen met a few days later "and discussed the group's idea of setting up voluntary birth control centers to combat illegitimacy and save welfare expenses," the Times Picayune reported. McKeithen did not object but announced that, "virtually," the state already had "voluntary birth control now."

In line with their bid to cut welfare spending and their racialized appeal to morality, Louisiana's councils called for open access to birth control and reproductive health clinics. "It is an outrage that Louisiana is the one state that does not have planned parenthood clinics," Singelmann complained at the Citizens' Council of Louisiana convention in March 1965 in Baton Rouge..$^{97}$ The Citizens' Council simultaneously pushed for stronger a implementation of Louisiana's statutes on the prohibition of common-law marriages, and Singelmann criticized the number of people on the state's "Aid to Dependent Children" provision..$^{98}$ The Council's demands for free birth control, easier access to Planned Parenthood clinics, and an end to common-law marriages, then, were not a sudden case of altruism or a feminist awakening but a calculated bid to cut off poor, predominantly black recipients from welfare, thereby reinforcing postMoynihan Report stereotypes about black families. In his speech, Singelmann referred to "persons in the lower income bracket [...] anxious to learn of planned parenthood" and the "thousands of dollars" of welfare provisions saved due to birth control programs in Chicago and North Carolina. 99 "[I]f we could get the Negro married and responsible for their children," Singelmann clarified the Council's intentions, "everyone would benefit." The anti-common-law-marriage provisions Louisiana's state law could serve as "a weapon we could use. We could accomplish miracles," ${ }^{100}$ he proclaimed, showing bold optimism that this line of argument would reinvigorate the Councils' political firepower.

Singelmann and fellow councilors tapped into a pervasive discourse on population growth, resource distribution, birth control, and family planning at the time. National and international anxiety about exponentially increasing population numbers, and appeals to curb social consequences like cycles of poverty, food and space shortages, and natural resource depletion, had found their way into Louisiana's local newspapers. ${ }^{101}$ As part of the federal War on Poverty, the Health, Education and Welfare Department (HEW) and the newly established Office of Economic Opportunity (OEO) allocated over a billion dollars to local birth control counseling initiatives across the nation between 1964 and 1967. In 1965, the Supreme Court ruled in Griswold v. Connecticut that states' ban on contraceptives for married couples was unconstitutional, and by 1970, fourty-eight of Louisiana's sixty-four parishes had established family planning clinics for low-income residents. ${ }^{102}$

In February 1966, seven months before Planned Parenthood's founder Margaret Sanger passed away, the Citizens' Councils of Louisiana's president Dr. Emile Ventre met fellow councilors in New Orleans. The group discussed the anticipated "opposition from the Catholic Church" to their plans to boost Planned Parenthood in Louisiana and thus receive OEO funds for birth control counseling in the state. Ventre assured the group that the bishops of Shreveport and New Orleans would be cooperative, but that the Council would have to assure a number of "points" before the Catholic Church agreed to the group's campaign for Planned Parenthood. These included the adherence to the 1964 Civil Rights Act's Title VI, which prohibits racial discrimination in federally financed projects, and an assurance that the Council's campaign would allow for supervision "to make sure [the] program goes along with what the Catholic Church 
wants." ${ }^{103}$ The state organization instructed local councils to convey information on Planned Parenthood, and to form a small committee to sponsor the Council's program. The committee was to be comprised of "Ladies, outsiders, and other persons as well as Citizens Council members." Ventre added that volunteer doctors to "staff a clinic" were particularly welcome. ${ }^{104}$

The Council was aware of the delicateness of its endeavor in predominantly Catholic southern Louisiana. It could, however, build on a growing chasm between the Catholic clergy and the laity in regard to birth control. After the Second Vatican Council (1962-1965), moderate Catholics had hoped that Pope Paul VI would relax the church's stance on "artificial" contraceptives. With a 7,000 word encyclical in 1967, however, Paul VI rejected all forms of birth control other than abstinence (and the temporary use of the rhythm method). The contrast between Catholic doctrine and lay practice thus sharpened, and a poll in the same year showed that thirty percent of Roman Catholics used artificial birth control and seventy percent had hoped for the Church to allow contraception. ${ }^{105}$

The Council made no mention of abortion in its Planned Parenthood campaign planning. Importantly, as the historian Caroline Hymel has noted, the Supreme Court's Roe v. Wade decision in 1973 "reflected a nation-wide consensus in favor of legalized abortion" that was mirrored in Louisiana, where "only 23 percent" completely disapproved abortion in $1975 .{ }^{106}$ With the exception of a 1974 SLCC publication that called Nelson Rockefeller an "internationalist and abortionist," Louisiana's Councils seemed to steer clear of the debate boosted by the Christian Right. ${ }^{107}$ The Council's own booster campaign, however, seems to have faltered without success. Planned Parenthood of Louisiana was not established as a statewide organization until 1984.

The Council was not out of the mainstream with its attempt to bolster the support for birth control counseling and family planning in the Pelican state. Indeed, it latched onto an emerging, supposedly progressive discourse on reproductive rights and gave it a white supremacist spin. The Council sought to capitalize on (inter-)national conversations and well-funded initiatives for social reform. Their goal was to ensure preferential treatment to white people and continued racial inequality by different means than segregation and disfranchisement: population control and welfare cuts to poor black families, disguised in the language of scientific and social progress and fiscal responsibility.

51 In the late 1960s, Louisiana indeed cut the "Aid to Families with Dependent Children" program (AFDC). Already in 1959, the state had passed a law that excluded women from the program if they had had "an illegitimate child" while enrolled for benefits. As a result, over 2,000 children lost their aid in 1960. After national and international protests, the law was abolished. ${ }^{108}$ The multiple cuts to the program's budget and mandatory work provisions, however, resulted in welfare activists' continued protests in 1968. ${ }^{109}$ CCGNO members openly mocked and demonized the group of black women who led the New Orleans Welfare Rights Organization. The Council called the women's criticism of welfare cuts "the funniest news story in years," if it "were not for the tragic aspect." C.E. Vetter denounced the group as "immoral women and their illegitimate children" who were "clamoring for more money to continue their immorality," while "decent, law-abiding citizens" paid for their lifestyle. "It is high time [that] the people of this state quit coddling this cancerous condition and force these people to be responsible for their acts by prosecuting them to the fullest of the law," Vetter added. 
${ }^{110}$ The Council movement in Louisiana thus interwove conservative ideology on individualism, morality, and personal and fiscal responsibility with white supremacy, painting black men and particularly black women as morally unfit, lazy, and promiscuous.

The most mainstream success in the late 1960s, however, came with the council movement's rhetorical focus on the conservative dogma of "freedom of choice" and "freedom of association," and they found allies in Governor McKeithen and Lieutenant Governor Aycock. The state legislature had subsidized the continuance of racial segregation in education by several grant-in-aid acts between 1954 and 1967, which sponsored children to attend private, segregated schools. By 1966, the grants program was putting a strain on Louisiana's budget and was $\$ 100,000$ short of funds. ${ }^{111}$ Federal courts, moreover, had systematically ruled against Louisiana's and other southern state's efforts to circumvent desegregation by pupil placement plans, re-zoning, and grant-in-aid programs. ${ }^{112}$

By 1969, fifteen years after the first Brown decision, HEW's and federal courts' patience with Louisiana was wearing thin. ${ }^{113}$ Louisiana segregationists had no intention of giving up, however, and the governor, who had declared that "segregation is the best of way of life for Louisiana" in 1966, supported the segregationist grassroots actions. In August 1969 , ten thousand whites assembled at Lake Charles stadium for a rally against school desegregation. The protest was organized by the newly formed "Concerned Citizens For Quality Education" (CCQE), a group with close ties to the American Party of Louisiana. The CCQE called for a holiday on October 13, termed "freedom of choice day," to protest integration through white school boycotts. ${ }^{114}$ Against the objections of Parent-Teacher Associations and the NAACP, McKeithen obliged. He declared October 13, 1969, "freedom of choice" day, but refrained from making it a compulsory holiday. ${ }^{115}$

Segregationists' high hopes to kick off another round of statewide defiance did not materialize, however. In Monroe, the civil rights group "The Black Citizens Council of Ouachita Parish" ironically designated October 14, 1969 as a holiday to "celebrate the death" of token desegregation. ${ }^{116}$ The state's segregationist elite and grassroots groups were no match to the combined powers of the federal executive and judiciary. By February 1970, integration was "becoming a social reality," and around thirty percent of the state's black children attended formerly white schools. ${ }^{117}$

The most ardent segregationists, among them the SLCC and the CCGNO, had still not given up, however. At the beginning of the 1970/1971 school year, anti-desegregation riots and fights between black and white students broke out after schools in Thibodaux, Terrebonne Parish, and Houma desegregated. In April 1971, the CCGNO launched another statewide white voter registration drive and kicked into gear for a 1972 Wallace presidential campaign. In 1972, the SLCC's president Jackson Ricau lauded Governor Edwin Edwards for sending 300 police officers to Southern University in Baton Rouge, where students had protested for weeks and occupied administration buildings in pursuit of better facilities and services. In the confrontation, a police officer killed two 20-year-old students, Leonard Brown and Denver Smith. ${ }^{118}$ Louisiana's organized grassroots segregationists could not muster the strength to mobilize substantial, public support for their continued propaganda, though.

56 The zenith of the White Citizens' Council Movement had passed in the second half of the 1960s, when federal legislation and court orders made effective, continued defiance of desegregation orders virtually impossible and the movement had splintered. A 
number of Louisiana's councils, nonetheless, proved adaptive and dynamic in their post-1965 activism. Councilors continued their fight for white supremacy - they not only fought to survive a changing landscape, but to create a next generation of Louisiana white supremacists, and to activate a broader spectrum of white people across the nation in favor of everyday white privilege. The councils showed creativity and political flexibility in aligning their white supremacist cause with varied aspects of conservative talking points and by appropriating civil rights language, and thus exemplified the fluidity of white supremacy and its ability to rejuvenate in mainstream conversations. Councilors allied with (fellow) extremist groups like the KKK and independents, Democrats, and Republicans alike when seeking and establishing ideological commonalities beyond a southern sectional crisis. The councils pushed for a white supremacist spin to conservatism not only in Louisiana, but on a national stage with their campaigns for Wallace, welfare cuts, and freedom of choice for whites. The state's segregationists lost the battle for Jim Crow, but they were a far cry from giving up on the battle for white supremacy, and the strategy to cloak the defense of white privileges in colorblind rhetoric would be a strategy that reverberates until today.

\section{NOTES}

1. "Editorial Opinion: The Wake," The Citizen, May 1968, Vol. 12, No. 8, 2.

2. "Non-Violence' Breeds Violence,"The Shreveport Journal (SJ), April 5, 1968, 8-A.

Shannon officially joined the staff of the Citizens' Councils of America in 1971, see

"Shannon Joins Citizens Council," The Shreveport Times (ST), September 21, 1971, 26.

3. Reprint of Jackson G. Ricau's letter, newspaper clipping, Opelousas Daily World (ODW), April 11, 1968, Kim Lacy Rogers/Glenda Stevens Collection, \#317, Box 2, Folder 15, Amistad Research Center, Tulane University, New Orleans (ARC); South Louisiana Citizens' Council (SLCC), The Citizens' Report, February 1975, Kim Lacy Rogers/Glenda Stevens Collection, \#317, Box 2, Folder 19, ARC.

4. See Kathryn L. Nasstrom, "Between Memory and History: Autobiographies of the Civil Rights Movement and the Writing of Civil Rights History," The Journal of Southern History 74, no. 2 (2008):: 330-331; Jacquelyn D. Hall, "The Long Civil Rights Movement and the Political Uses of the Past," The Journal of American History 91, no. 4 (2005), 1234. 5. Hall, "The Long Civil Rights Movement and the Political Uses of the Past," 1234, 1254; Frank Newport, "Martin Luther King Jr.: Revered More After Death Than Before," Gallup News Service, January 16, 2006, https://news.gallup.com/poll/20920/martinluther-king-jr-revered-more-after-death-than-before.aspx. See also Jeanne Theoharis, A More Beautiful and Terrible History: The Uses and Misuses of Civil Rights History (Boston: Beacon Press, 2018).

6. Hall, "The Long Civil Rights Movement and the Political Uses of the Past," 1234-1235, 1263.

7. See Eric Arnesen, "Reconsidering the 'Long Civil Rights Movement"' Historically Speaking 10, no. 2 (2009): 31-34; Sundiata Keita Cha-Jua and Clarence Lang, "The "Long 
Movement" as Vampire: Temporal and Spatial Fallacies in Recent Black Freedom Studies." The Journal of African American History 92, no. 2 (2007): 265-88.

8. George Lewis, Massive Resistance: The White Response to the Civil Rights Movement (London/New York: Hodder Arnold, 2006), 8-9. Also see Numan V. Bartley, The Rise of Massive Resistance: Race and Politics in the South During the 1950's, 2nd ed. (Baton Rouge: Louisiana State University Press, 1997).

9. See Lewis, Massive Resistance, 4. Also see Matthew D. Lassiter, The Silent Majority: Suburban Politics in the Sunbelt South (Princeton: Princeton University Press, 2007).

10. Rolph, Resisting Equality: The Citizens' Council, 1954-1989 (Baton Rouge: Louisiana State University Press, 2018), 3.

11. Neil R. McMillen, The Citizens' Council. Organized Resistance to the Second Reconstruction 1954-64, 2nd ed. (Urbana: University of Illinois Press, 1994), 59-61.

12. McMillen, The Citizens' Council, 61-63.

13. McMillen, The Citizens' Council, 64-67; also see Donald E. Devore and Joseph Logsdon, Crescent City Schools: Public Education in New Orleans 1841-1991 (New Orleans: University of Southwestern Louisiana, 1991), 239.

14. McMillen, The Citizens' Council, 65-66.

15. The Citizens' Report, SLCC, December 1967, Kim Lacey Rogers and Glenda Stevens Collection, 317, Box 2, Folder 15, Amistad Research Center, Tulane University, New Orleans (ARC).

16. McMillen, The Citizens' Council, 69-70.

17. Devore and Logsdon, Crescent City, 179-225; Liva Baker, The Second Battle of New Orleans: The Hundred-Year Struggle to Integrate the Schools (New York: Harper Collins Publishers, 1996), 3; Davison M. Douglas, "Bush v. Orleans Parish School Board and the Desegregation of New Orleans Schools," unpublished manuscript, 2, 56-57, https:// www.fjc.gov/sites/default/files/trials/bush.pdf; New Orleans Improvement League, "A Study of some tangible Inequalities in the New Orleans Public Schools," ca. 1957, 2, A.P. Tureaud Papers, Reel 11, Box 13, frame 392, ARC; "Louisiana," Southern School News, December 1954, 6.

18. Devore and Logsdon, Crescent City, 232; Baker, The Second Battle, 3; Douglas, Bush, 3.

19. McMillen, The Citizens' Council, 65-66.

20. McMillen, The Citizens' Council, 68.

21. McMillen, The Citizens' Council, 71.

22. Glen Jeansonne, Leander Perez: Boss of the Delta (Baton Rouge: Louisiana State University Press, 1977), 240-241.

23. Adam Fairclough, "A Political Coup d'État? How the Enemies of Earl Long Overwhelmed Racial Moderation in Louisiana," in Massive Resistance: Southern Opposition to the Second Reconstruction, ed. Clive Webb (Oxford/New York: Oxford University Press, 2005), 70. See also McMillen, The Citizens' Council, 68.

24. Charles L. Barnett to William Rainach, February 24, 1962, William M. Rainach Papers, 087, Box 15, Folder 152, Northwest Louisiana Archives, Louisiana State University Shreveport (LSUS); William Rainach to Charles L. Barnett, December 24, 1962, Rainach Papers, Box 15, Folder 152, LSUS.

25. "Freedom Bus," The Louisiana Weekly, April 14, 1962, 1 and 7; Leslie H. Whitten, "Louisiana Cancels Transfer Of Negro Families to District," The Washington Post, April 26, 1962, B6; circular letter by the Citizens' Council of Louisiana (signed by William Rainach, Ned Touchstone, and Charles L. Barnett), received on June 30, 1962, Rainach Papers, Box 15, Folder 152, LSUS. See also Clive Webb, ““A Cheap Trafficking in Human 
Misery': The Reverse Freedom Rides of 1962." Journal of American Studies 38, no. 2 (2004): 249-71.

26. Touchstone to Rainach, April 22, 1964, Rainach Papers, Box 15, Folder 152, LSUS; Minutes of the meeting of the Citizens' Council of Louisiana's board of directors, Alexandria, April 25, 1964, Rainach Papers, Box 15, Folder 152, LSUS; Touchstone to Rainach, February 21, 1964, Ned Touchstone Papers, 392, Box 5, Folder 64, LSUS; Interview with William M. Rainach, August 19, 1977, 12, interviewer: Hubert Humphreys, Homer, Louisiana, Oral History Collection, \#17, LSUS; see, for example, “ADL- Superpressure Group - Gestapo of the Establishment," entered into the Congressional Record by John Rarick, December 6, 1971 and December 15, 1971, Touchstone Papers, Box 1, Folder 15; “A Quick Note, Dictated by Mr. Ned Touchstone" to "Mr. Graham," October 11, 1973, Touchstone Papers, Box 3, Folder 31; “Confidential Memorandum To Taylor O’Hearn From N.O.T.," by Ned Touchstone, November 7, 1972, Touchstone Papers, Box 8, Folder 128 , LSUS.

27. The Citizens' Report, SLCC, July 1964, October 1964, and November 1964, Kim Lacey Rogers and Glenda Stevens Collection, 317, Box 2, Folder 12, ARC; "Lyons Given Endorsement By Council," ST, February 29, 1964, 4.

28. The Citizens' Report, SLCC, January 1965, Extra, and September-October 1965,Kim Lacey Rogers and Glenda Stevens Collection, Box 2, Folder 13, ARC; also see "Roman Catholics: Historic Bishop," Time Magazine, October 8, 1965, 70.

29. A CCGNO board member and one of its most active public speakers between 1964 and 1966, Jack M. Helm, was also a member of the United Klans of America in Louisiana, see "LA. Men Silent At Klan Probe," The Times Picayune (TP), January 8, 1966, 1. On the Mississippi Council's strategy see Stephanie R. Rolph, "The Citizens' Council and Africa: White Supremacy in Global Perspective," The Journal of Southern History 82, no. 3 (2016): 621-623.

30. Adam Fairclough, Race \& Democracy: The Civil Rights Struggle in Louisiana, 1915-1972 (Athens: University of Georgia Press, 1999), 345-351.

31. Anti-Defamation League of B'NaiB'Rith, FACTS, Domestic Report, May 1965, Vol. 16, no. 3, A.P. Tureaud Papers, 1909-1972, Series III, reel 11, ARC.

32. Southern Conference Educational Fund, "The Southern Patriot," Vol. 23, No. 5, May 1965, Tureaud Papers, Series III, reel 15, ARC.

33. "Thousands Jam Klan Rally Near Bogalusa," ST, July 22, 1965, 7-D; Gavin Scott, "Court Orders Klan to Halt Intimidation at Bogalusa," ST, December 2, 195, 4-A; Fairclough, Race \& Democracy, 356.

34. Fairclough, Race \& Democracy, 356-366; Gavin Scott, "Court Orders Klan to Halt Intimidation at Bogalusa," ST, December 2, 1965, 4-A; see Simon Wendt, " "Urge People Not to Carry Guns": Armed Self-Defense in the Louisiana Civil Rights Movement and the Radicalization of the Congress of Racial Equality." Louisiana History 45, no. 3 (2004): 270-273.

35. "Return of Conservatism Urged at Bogalusa Rally," TP, May 8, 1965, 1; "Thousands Jam Klan Rally," 7-D; “Delay in Bogalusa Suggested," TP, May 5, 1965, 1; "Marchers Hit," TP, July 13, 1965, 14; “'Keep Agitators Out,' Says Ricau,” TP, July 18, 1965, 2.

36. "Racial Session," TP, April 24, 1965, 1 and 9; Fairclough, Race \& Democracy, 364. In August 1965, Louisiana also set up its first statewide biracial committee, comprised of 42 civil leaders picked by Governor McKeithen, see "La. Bi-Racial Committee Named," Alexandria Daily Town Talk (ADTT), August 24, 1965, section B, 5.

37. "Racial Session," TP, April 24, 1965, 9. 
38. "Bogalusa Rally Plans Are Made: May 7 Is Selected by Conservative Group," TP, April 28, 1965, section 2, 2; "Delay in Bogalusa Rally Suggested," 1 and 3; "Return of Conservatism Urged," 1.

39. "Bogalusa Klan Names Are Revealed by Solon," ST, October 30, 1965, 9-A; Don Lee Keith and L.G. Hountha, "Security Tight For 2 Marches," TP, July 12, 1965, 1.

40. "LA. Men Silent At Klan Probe," 1.

41. "Return of Conservatism Urged," 1 .

42. "Return of Conservatism Urged," 1 .

43. Kim Phillips-Fein, "Conservatism: A State of the Field." The Journal of American History 98, no. 3 (2011): 727.

44. See George Lewis, "Virginia's Northern Strategy: Southern Segregationists and the Route to National Conservatism." The Journal of Southern History 72, no. 1 (2006): 145; Lisa McGirr, Suburban Warriors: The Origins of the New American Right (Princeton/Oxford: Princeton University Press, 2001); David W. Noble, "Conservatism in the USA," Journal of Contemporary History 13, no. 4 (1978): 635-52; Phillips-Fein, “Conservatism": 723-743; Julian E. Zelizer, "Rethinking the History of American Conservatism." Reviews in American History, 38, no. 2 (2010): 367-92.

45. Neil Gross, Thomas Medvetz and Rupert Russell, "The Contemporary American Conservative Movement." Annual Review of Sociology 37 (2011): 330.

46. “Citizens Council Rally Planned," TP, August 23, 1965, section 3, 3.

47. Don Lee Keith and L.G. Hountha, "Security Tight For 2 Marches," TP, July 12, 1965, 1; "Bogalusa Rejects Plan," TP, July 13, 1965, 5.

48. "Rau Addresses Parent Group," TP, March 25, 1963, section 2, 5; "Return of Conservatism Urged," 1; see Lance E. Hill, Deacons For Defense (Chapel Hill: University of North Carolina Press, 2006), 126.

49. “'Invocation' at Klan Rally Is Not According to Grand Dragon's Hoyle," ADTT, May

24, 1965, 25.

50. "Marchers Hit," 14.

51. "Thousands Jam Klan Rally," 7-D.

52. W.F. Minor, “Miss. Figures At Klan Rally,” TP, October 25, 1965, 7.

53. “LA. Men Silent At Klan Probe," TP, January 8, 1966, 1.

54. Minutes of the meeting of the Citizens' Councils of Louisiana's board of directors, February 19, 1966, 3, Ned Touchstone Papers, 392, Box 5, Folder 63, LSUS; “Citizens Council to Hear Speakers," TP, October 12, 1965, 16; "Draft Director Suspends Helm," TP, March 16, 1966, 1.

55. “KKK Rift Seen in Baton Rouge," TP, March 13, 1967, section 3, 16; Jack Owens, “Bombing Order Denied By Helm," TP, October 17, 1967, 1.

56. See Fairclough, Race \& Democracy, 367; Kenneth F. Englade, "Search for Ambushers of Policemen Continues," ST, June 2, 1965, 10-A; Ed McCusker, "White Man Is Held in Death of Bogalusa Negro Deputy,” ST, June 4, 1965, 3-A; John Fahey, “M’Elveen Case Hearing Aired," TP, June 8, 1965, 3.

57. Interview with William M. Rainach, August 19, 1977, 5, LSUS.

58. "Reject Funds: Councils‘ Plea,“ TP, January 31, 1965, 8.

59. “Get Organized, Perez Advises," TP, September 2, 1965, section 2, 25; "Probe of Reds' Role Is Urged," TP, June 29, 1965, 7; “Drive Starts in Plaquemines," TP, August 18, 1965, 7; “375 Are Listed To Vote In N.O.," TP, August 24, 1965, 12; “Band Together, Perez Cautions," TP, October 6, 1966, section 3, 12; also see Jeansonne, Leander Perez, 241. 
60. "Citizen Council Members Call on Gov. McKeithen," newspaper clipping, ca. March 1965, Wellborn Jack Papers, 425, Box 74, Folder 2037, LSUS.

61. Circular letter by Courtney Smith to "Shreveport Subscribers to the Councilor and Shreveport Citizens Council Members," September 13, 1965, Wellborn Jack Papers, Box 74, Folder 2036, LSUS.

62. Circular letter by the CCGNO, undated, ca. February 1966, signed by George Singelmann, Leander Henry Perez Papers, 1954-1969, Box 1, Folder "Hessler Campaign, CC Letter," New Orleans Public Library, Special Collections (NOPL).

63. Kent B. Germany, New Orleans After The Promises: Poverty, Citizenship, and the Search for the Great Society (Athens and London: The University of Georgia Press, 2007), 250.

64. Charles M. Hargroder, "Deputies Raid La. Core Office," TP, October 13, 1963, 29; Ben Thomas, "LeBlanc, Rarick Force La. Demo House Runoffs," TP, August 15, 1966, section 2, 2; Bill Neikirk, “Rarick Ousts Rep. Morrison,” TP, September 25, 1966, 1.

65. Fairclough, Race \& Democracy, 373.

66. Bill Neikirk, "Rarick Claims Election Fraud," TP, August 9, 1966, 10; "Rarick Ousts," 1; “Gov. McKeithen," TP, November 5, 1967, 2.

67. "Rarick Speech Hailed By D.A.R.," TP, April 18, 1968, 19; "Rarick Behind Wallace Drive," TP, September 20, 1967, 12; Edgar A. Poe, “Demo Liberals Strip Rarick of Seniority," TP, January 30, 1969, 1.

68. Sara Diamond, Roads to Dominion: Right-Wing Movements and Political Power in the United States (New York and London: The Guilford Press, 1995), 85.

69. Speech by George C. Wallace, June 17, 1964, Baton Rouge, Louisiana, Brooks Read Collection, 21522-35P, Folder 13, Louisiana State Archives, Baton Rouge (LSA); Ned Touchstone in a circular letter to members of the board of directors and council presidents of the Citizens' Councils of Louisiana, received April 2, 1964, Rainach Papers, Box 15, Folder 152, LSUS.

70. "Iron Hot, Wallace Claims," TP, February 18, 1967, 2; Special Release, SLCC, MayJune 1966, Kim Lacey Rogers and Glenda Stevens Collection, Box 2, Folder 14; ARC; The Citizens' Report, Special, SLCC; March-April 1967, Kim Lacey Rogers and Glenda Stevens Collection, Box 2, Folder 15, ARC; advertisement for the $12^{\text {th }}$ Annual Leadership Conference of the Ciitzens' Councils of America, TP, February 15, 1967, 27.

71. "Gov. Williams Lauds Wallace," TP, October 26, 1968, 19; "Wallace Sign-Up Held in Parish," Opelousas Daily World (ODW), April 30, 1968, 12; Carroll P. Trosclair, "Citizens Council Now Working For Wallace," ODW, October 6, 1968, 4; see James H. Gillis, "Wallace Is Given Plurality in Record Louisiana Vote," TP, November 7, 1968, 1.

72. K. Mack Sisk, "Wallace Party Control Issue," ODW, December 3, 1968, 4; Adras LaBorde, "Wallecites Organize," ADTT, December 6, 1968, 6; Gerald Hambleton, “American Party Lays Organizational Plans," ADTT, December 8, 1968, 6; "American Party Settles Squabble," ODW, December 10, 1968, 11.

73. "American Party Organizers in Weekend Session in Baton Rouge," Opelousas Daily News, January 28, 1969, 16; "Efforts to Get Voters to Change Registration Prove Ineffectual," ADTT, January 12, 1969, 5; “American Party Officials Meet," ODW, March 2, 1969, 2; "Democrats Thwart GOP, American Party Efforts," TP, February 2, 1972, 14; “State's Negro Voters Near Double Since '64," States-Item, October 22, 1968, newspaper clipping, Charles B. Rousseve Papers, 320, Box 4, Folder 16, ARC; C.E. Vetter to Ned Touchstone, undated, ca. May 1969, Touchstone Papers, Box 6, Folder 85, LSUS. 
74. “South Nixon's If No Wallace," TP, May 27, 1972, 21; Fairclough, Race \& Democracy, 441; also see Joseph A. Aistrup, The Southern Strategy Revisited: Republican Top-Down Advancement in the South (Lexington: The University Press of Kentucky, 2015). 75. Jim Leeson, "Private Schools For Whites Face Some Hurdles," Southern Education Report (SER), November 1967, 13-15; Edward J. Lepoma, "N.O. Population Report Released; Little Integration Noted Since 1950," States-Item, September 19, 1969, newspaper clipping, Rousseve Papers, Box 4, Folder 17, ARC. Also see Kevin M. Kruse, White Flight: Atlanta and the Making of Modern Conservatism (Princeton: Princeton University Press, 2005).

76. Memorandum by Courtney Smith, May 27, 1966, Touchstone Papers, Box 8, Folder 125, LSUS; letter by Wellborn Jack to the CCGNO, January 25, 1965, Wellborn Jack Papers, Box 75, Folder 2036, LSUS.

77. Circular letter by Courtney Smith to "All Council Presidents and Secretary Treas.," undated, ca. 1966, Touchstone Papers, Box 8, Folder 125, LSUS.

78. CCGNO Bulletin, undated, ca. May 1964, Perez Papers, Box 1, Folder "Miscellaneous," NOPL; advertisement by the CCGNO, The Councilor, February 16, 1965, newspaper clipping, Touchstone Papers, Box 35, Folder 1965, LSUS; “Leftists Reminded of School-Mix Failures," The Councilor, May 9, 1964, 1.

79. CCGNO Bulletin, undated, ca. May 1964, Perez Papers, Box 1, Folder "Miscellaneous," NOPL.

80. Robert C. Maynard, "Black Nationalists Predict Race War," The Washington Post, September 24, 1967, section C, 1 . This was the first of a seven-article series on "The Black Revolutionaries."

81. John Chamberlain, "King and Students Could Touch Off Guerilla Warfare Summer," ST, March 31, 1968, 3-B; John Steen, "Dr. King Rallies War Protestors, Black Power for Demonstrations, SJ, February 7, 1968, 3; The Citizens' Report, SLCC, February 1966, Kim Lacey Rogers and Glenda Stevens Collection, Box 2, Folder 14, ARC.

82. “Citizens Council Series to Begin," TP, May 2, 1967, section 3, page 5.

83. "Citizens Council Against Farmer," February 24, 1969, 18; “Citizens Council Urges Change," TP, February 18, 1968, 8.

84. "Want Flag Restored," ADTT, June 6, 1969, 7.

85. The Citizens' Report, SLCC, March 1964 and April 1964, Kim Lacey Rogers and Glenda Stevens Collection, Box 2, Folder 12, ARC; “Citizens Council to Hear Speakers," TP, October 12, 1965, 16; see, for example, "Self-Defense Spray Helps Protect American Women," The Southern Review, July 16, 1969, Touchstone Papers, Box 45 (no folders), LSUS.

86. “Council Seeks Rapist Death,” TP, January 10, 1968, 8. Not until 1978 were prison population statistics collected by race; the Louisiana State Penitentiary (Angola), however, was infamous for its mistreatment of black prisoners.

87. See minutes of the meeting of the Shreveport Citizens' Council, August 13, 1963 and August 15, 1963, Touchstone Papers, Box 5, Folder 62, LSUS.

88. See Brückmann, Rebecca. "Massive Resistance and Southern Womanhood: Women's Activities in the Segregationist Counter-Movement." Ph.D. dissertation, Freie Universitaet Berlin, 2014.

89. See Jeansonne, Leander Perez, 264-265.

90. "Woman Ousted By Church Renounces It," ST, December 23, 1969, 2-A; Wesley Jackson, "Excommunicate Holds to Her Views," TP, September 24, 1978, 16. On Perez's readmission, which only came to be known to the public at his funeral and evoked 
protests, see "Priests Object To Perez Rites," undated newspaper clipping, ca. March 1969 and "Bishop Perry Defends Rites," TP, March 26, 1969, newspaper clipping, Rousseve Papers, Box 4, Folder 17, ARC.

91. "New Archbishop Accepts Pastoral Staff in Orleans," ST, October 14, 1965; John Lang, "Mrs. Gaillot Fights to Keep Son Out of Integrated Unit," ADTT, September 4, 1965, section B, 4; "N.O. Woman Loses Bid to Label Blood," ST, July 28, 1972, 36.

92. The Citizens' Report, SLCC, May-June 1966, Kim Lacey Rogers and Glenda Stevens Collection, Box 2, Folder 14, ARC.

93. The Citizens' Report, SLCC, December 1966, Kim Lacey Rogers and Glenda Stevens Collection, Box 2, Folder 14, ARC.

94. The Citizens' Report, SLCC, January 1969, Kim Lacey Rogers and Glenda Stevens Collection, Box 2, Folder 16, ARC.

95. "Reject Funds; Councils' Plan," TP, January 31, 1965, 8.

96. "McKeithen Doubts Recall Actions Over Compliance," TP, February 13, 1965, 4.

97. Chet Folkes, "Citizens Councils Object to Welfare Expenses in State," States-Item, newspaper clipping, March 13, 1965, Wellborn Jack Papers, Box 74, Folder 2037, LSUS.

98. Folkes, "Citizens Councils Object to Welfare Expenses in State," Wellborn Jack Papers, Box 74, Folder 2037, LSUS.

99. Folkes, "Citizens Councils Object to Welfare Expenses in State," Wellborn Jack Papers, Box 74, Folder 2037, LSUS. On the link between birth control, welfare, and racism, see Johanna Schoen, Choice and Coercion: Birth Control, Sterilization, and Abortion in Public Health and Welfare (Chapel Hill: The University of North Carolina Press, 2005), 3-13. 100. "Citizens Councils Object."

101. See, for example, "Solons Told Birth Control Urgent Need," Monroe News-Star (MNS), January 19, 1966, 1; William J. Eaton, "Poverty Projects Include Date on Birth Control," Shreveport Times, January 15, 1966, 11; "Birth Control Clinics Slated All over India," ODW, March 27, 1966, 11; Patricia McCormack, "Battle to Clip Stork's Wings Advances, but Not Fast Enough," ST, June 30, 1968, 7-E.

102. "Anti-Poverty Program May Finance Projects Involving Birth Control, "ADTT, January 15, 1966, A-5; "Louisiana Birth Plan Program Lauded As No. 1 in the Nation," Basile Weekly, January 21, 1970, 3. Planned Parenthood criticized the OEO for exempting unmarried women and women not living with their husband from its birth control distribution. Although federal funds, which accounted for $90 \%$ of the Office's budget, prohibited the disbursement of contraceptives to singles, the remaining $10 \%$ of private funds could be used for this purpose. HEW, in contrast, did not limit the disbursement of contraceptives. See "Congress May Pass Birth Control Bill," ADTT, June 13, 1966, A-3. With Eisenstadt v. Baird in 1972, the Supreme Court confirmed unmarried people's right to contraceptives.

103. Minutes of the meeting of the board of directors, Citizens' Councils of Louisiana, February 19, 1966, Touchstone Papers, Box 5, Folder 63, LSUS.

104. Minutes of the meeting of the board of directors, Citizens' Councils of Louisiana, February 19, 1966, Touchstone Papers, Box 5, Folder 63, LSUS; letter by Courtney Smith to "All Local Councils," undated, ca. 1966, Touchstone Papers, Box 8, Folder 125, LSUS.

105. Dennis Redmond, "Pope Paul VI Rejects All Artificial Birth Controls," ST, July 30, 1968, 5; "How Catholics View Their Church, Newsweek, March 20, 1967, 71-72; "Magazine Says Catholics Polled on Birth Control," MNS, March 13, 1967, 5; see also Marian Faux, Roe v. Wade: The untold story of the landmark Supreme Court decision that made abortion legal (1st Cooper Square Press ed. New York: Cooper Square Press, 2001), 184-185. 
106. Caroline Hymel, "Louisiana's Abortion Wars: Periodizing the Anti-Abortion Movement's Assault on Women's Reproductive Rights, 1973-2016." Louisiana History 59, no. 1 (2018): 68.

107. The Citizens' Report, SLCC, November 1974, Vol. 16, No.7, Kim Lacey Rogers and Glenda Stevens Collection, 317, Box 2, Folder 18, ARC.

108. Germany, New Orleans After The Promises, 225-229.

109. Germany, New Orleans After The Promises, 229-231.

110. "Protest of Cut in Welfare Hit," TP, November 25, 1968, 2; Germany, New Orleans After The Promises, 231.

111. Jeansonne, Leander Perez, 303; "Private School Funds Studied," TP, October 6, 1966, section $3,12$.

112. See "Citizens' Council Praises Louisiana Grant-in-Aid," TP, April 12, 1966, section 3, 11; “School Grants-In-Aid Law Voided By Court," TP, August 27, 1967, 1; Jeansonne, Leander Perez, 303-305; Fairclough, Race \& Democracy, 437.

113. See Jim Leeson, “Desegregation: A New Approach, A New Deadline," SER, January/ February 1968, 14-17; Vernon A. Guidry Jr., "HEW Threatens Action Against LSU on Mixing," SJ, June 6, 1969, 1; Margaret Martin, "School Board Ordered To Submit New Plans For Desegregation By July 5," SJ, June 6, 1969, 1. On differences between the Johnson and the Nixon administrations' approach to the desegregation mandate, see James K. Batten, “The Nixonians and School Desegregation," SER, June 1969, 22-28. 114. G. Michael Harman, "Whie Citizens React Quickly To Total Desegregation Order," ODW, August 17, 1969, 5; M. Gene Mearus, "B.R. Protest March Draws Large Crowd," ADTT, August 17, 1969, 1; Fairclough, Race \& Democracy, 442-443; Vernon A. Guidry Jr., “Citizens Group Asks For School 'Holiday'," ADTT, September 28, 1969, 1.

115. Vernon A. Guidry Jr., "'Choice Day' Proclaimed; Legal Action Threatened," TP, October 9, 1969, 8; “'Freedom of-Choice Day' Set," TP, October 13, 1969, 18.

116. “'Freedom' Day Is Uneventful," TP, October 14, 1969, 12; “Negro Group to Observe 'Death' Of Choice Plan," ODW, October 10, 1969, 5.

117. Fairclough, Race and Democracy, 444.

118. C.M. Hargroder and Claire Punkey, "Parish State of Emergency Is Proclaimed," TP, September 22, 1970, 1 and 2; “White Voters' Drive Launched," TP, April 3, 1971, section 4, 3; "Ricau Praises Edwards Move," TP, November 30, 1972, section 7, page 16.

\section{ABSTRACTS}

This article examines the development of Massive Resistance, in particular Citizens' Councils, in Louisiana after the council movement in the South had passed its zenith when being unable to prevent the passage of federal civil rights and voting rights legislation. This article argues that grassroots white supremacist groups in Louisiana faced a winding path of decline and revitalization, and a number of councils proved adaptive to the changing political, social, and economic landscape by devising activist strategies that focused on direct action, white voter registration, and tapping into broader conservative discourses on law and order, welfare, and morality. Similar to questions about a "long civil rights movement," white supremacist 
resistance against the civil rights movement did not vanish in the latter half of the 1960s but transformed its rhetoric while seeking to align with the conservatism.

\section{INDEX}

Keywords: 1960s; Civil Rights; Citizens' Councils; Conservatism; Critical Whiteness; Grassroots; Gender; Louisiana; Massive Resistance; New Right; Racism; Voting Rights; Wallace; White Supremacy.

\section{AUTHOR}

\section{REBECCA BRÜCKMANN}

Rebecca Brückmann is an Assistant Professor of North American History and its transcultural context at Ruhr-University Bochum, Germany. She received her PhD from the Graduate School of North American Studies at Freie Universität Berlin. Her research interests focus on Southern history, the history of racialization, and borderlands history. She has published several articles on women in white supremacist movements and on racism in cultural production. 